\title{
Hierarchy Of GAAP vs. IFRS - The Case Of Bankruptcy Accounting
}

Daniel L. Haskin, University of Central Oklahoma, USA

Teresa E. Haskin, Certified Public Accountant, Edmond, Oklahoma, USA

\begin{abstract}
With increased movement toward convergence of major accounting principles between U.S. GAAP and IFRS, the issue of which authoritative source should be referenced becomes increasingly important. An important question is: what is the hierarchy of authority for pronouncements and documents under U.S. GAAP and IFRS? FASB Accounting Standards Codification is the single official source of authoritative U.S. GAAP. The hierarchy under international standards is less clear. The IASB promulgated a hierarchy in IAS 8, but interpretation concerning many issues is required. There are several issues not addressed at all by IFRS and one of these is bankruptcy accounting. ASC 852 is the guidance for bankruptcy accounting under U.S. GAAP. This study will investigate whether companies in countries which use IFRS are influenced by the guidance of ASC 852 when confronted with bankruptcy. A review of the financial statements of bankrupt companies in countries using or converting to IFRS was conducted into the reporting of reorganization-type bankruptcies.
\end{abstract}

Keywords: IFRS; GAAP; IASB; IAS 8; Convergence; Bankruptcy

\section{INTRODUCTION}

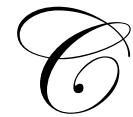

onvergence of accounting principles between the U.S. and other countries has become a major topic of discussion for accounting practitioners and academics in the last few years, mainly because the SEC is pushing U.S. GAAP toward harmony with IFRS. Among the major justifications for convergence is comparability between the financial statements of different countries. Most major differences between GAAP and IFRS are being addressed by joint projects between the FASB and the IASB. However, there are many accounting issues that are not being addressed by joint efforts of the FASB and the IASB and are not on the agenda for future projects. Among these omitted issues are such important topics as insurance, extractive industries, debt restructuring and bankruptcy. This paper is concerned with future accounting for reorganization-type bankruptcies as accounting standards are converged. In the United States, the accounting for Chapter 11 bankruptcy under U.S. GAAP is governed by SOP 90-7 (now ASC 852 under the new codification), but there is no comparable accounting rule under IFRS. A question arises about the accounting treatment of companies undergoing Chapter 11 reorganization and equivalent reorganization under bankruptcy laws in other countries. Will financial statements of companies under reorganization in the U.S and countries where IFRS is required be comparable?

\section{HIERACHY OF GAAP \& IFRS}

In the U.S., authority for the GAAP hierarchy previously resided in Auditing Standard No. 69, The Meaning of Present Fairly in Conformity with Generally Accepted Accounting Principles, until 2008 when the FASB issued Statement on Financial Accounting Standards No. 162, The Hierarchy of Generally Accepted Accounting Principles. The GAAP hierarchy set forth the level of authority attributed to a given accounting pronouncement or document.

In 2009, the Financial Accounting Standards Board (FASB) issued Statement of Financial Accounting Standards No. 168, "The FASB Accounting Standards Codification and the Hierarchy of Generally Accepted Accounting Principles - a replacement of FASB Statement No. 162" (FASB, 2009). SFAS 168 established the FASB 
Accounting Standards Codification (ASC) as the source of authoritative accounting principles recognized by the FASB to be applied in the preparation of financial statements in conformity with U.S. generally accepted accounting principles (GAAP). The intent of the ASC was to restructure the 17 sources of GAAP literature and 5 sources of SEC literature into a single source of authoritative literature.

For countries where IFRS is required, IAS 8 (IASB, 2003), IASB introduced a hierarchy of accounting rules that should be followed by preparers in seeking solutions to accounting problems. The hierarchy according to IAS 8 is:

1. Refer first to IAS/IFRS and their Interpretations when these specifically apply to a transaction or condition.

2. If there is not a directly applicable standard, judgment is to be used to develop and apply an accounting policy that is relevant to the economic decision-making needs of the users, and is reliable in that the financial statements: represent faithfully the financial position, financial performance and cash flows of the reporting entity; reflect the economic substance of transactions, events and conditions, rather than merely the legal forms thereof; are neutral; are prudent; and are complete in all material respects.

3. If this is not possible, the preparer should then look to recent pronouncements of other standard setters that use a similar conceptual framework to develop its standards, as well as other accounting literature and industry practices that do not conflict with higher-level guidance. Only if that also fails should the preparer look to the IASB Framework directly, and attempt to draw inferences regarding specific applications that have not been formally addressed in promulgated standards.

It seems that IASB is saying that if IFRS does not cover a subject, the preparer should look to national standards, and the most obvious choice for US companies would be U.S. GAAP.

\section{REVIEW OF BANKRUPTCY LAWS}

An examination of the bankruptcy laws in the United States, Canada, and the United Kingdom follows in order to set the background for the discussion of accounting for bankruptcies in various countries.

\section{United States Bankruptcy Laws}

Chapter 11 bankruptcy in the United States is a form of bankruptcy reorganization available to individuals, corporations, and partnerships, and is generally chosen by large businesses wishing to restructure their debt. The debtor company usually is allowed to operate the bankrupt company under the supervision of the court and for the benefit of the creditors under the concept of "debtor in possession." The debtor in possession is a fiduciary for the creditors and may be replaced by a trustee if it is ineffective or otherwise remiss in its management of the insolvent company.

A creditors committee is usually appointed by the court to represent the creditors. The bankruptcy plan is confirmed upon the vote of the creditors, who are divided into classes based on the characteristics of their claims. Their votes are proportionate to the amount of their claim against the bankrupt company. If the debtor does not have enough creditor votes to confirm the plan, it can attempt to "cram down" a plan by meeting certain statutory tests.

The rate of success for Chapter 11 reorganizations is generally estimated to be less than $10 \%$.

\section{Canadian Bankruptcy Laws}

Bankruptcy and insolvency is a matter of federal jurisdiction in Canada as it is in the United States, while property rights are governed by the provinces. Consequently, a combination of federal and provincial law rules Canadian bankruptcy processes. Canada has two principal insolvency laws:

1. Bankruptcy and Insolvency Act (BIA) and,

2. Companies Creditors Arrangement Act (CCAA). 
The provisions of the Bankruptcy and Insolvency Act set out the rights accorded to each class of creditors. The provisions of the Act must be followed carefully, in order that these rights and claims of creditors are honored precisely in accordance with the law. An accounting tool very useful in the administration of bankrupt companies is the statement of affairs. A company may also take action voluntarily under the BIA to enter bankruptcy in order to gain temporary protection from creditors.

The Companies' Creditors Arrangement Act, which is designed to facilitate compromises and arrangements between companies and their creditors, provides similar protection. Voluntary bankruptcy and arrangements under the CCAA are also administered by the Official Receiver and private sector trustees. Under the CCAA, the Statement of Affairs is a special, extended, balance sheet which sets out not only the book values of assets and liabilities, but also provides:

1. Estimated current values of assets, and

2. Amounts pledged as security and estimated amount available to meet unsecured claims.

The objective of the statement of affairs is to provide a summary analysis of the financial position of the firm and of the prospects of the various categories of creditors in liquidation.

\section{Bankruptcy Laws in the United Kingdom}

In the United Kingdom (House of Commons, 2010), an insolvent company can be liquidated in a process equivalent to U.S. Chapter 7 Bankruptcy or rescued in administration which is similar to U.S. Chapter 11 Bankruptcy. Both have the purpose of rescuing a viable business in temporary financial difficulty. The British bankruptcy laws were updated in 2002 with the passage of EA 2002. Many critics argue that EA 2002 should have gone further to reform British bankruptcy and introduced the United Kingdom to procedures similar to Chapter 11 proceedings in the United States. EA 2002 failed to introduce:

1. the concept of "debtor in possession,"

2. the concept of debtor in possession financing arrangements, and provisions to make unenforceable provisions of leases,

3. and executor contracts that terminate because of bankruptcy filing.

\section{REQUIREMENTS OF ASC 852}

Prior to the issuance of SOP 90-7 (Now ASC 852) (AICPA, 1990), in November 1990, there existed a diversity of accounting practices concerning companies emerging from Chapter 11 bankruptcy. SOP 90-7 has provided guidance for entities that have emerged from Chapter 11 under confirmed plans.

Financial reporting for an entity in Chapter 11 reorganization should chart the progress of the entity throughout the reorganization process. Two distinct parts mark the progress of the entity. The first part is the period between the filing of the Chapter 11 petition and the emergence of the firm from Chapter 11. The second part is the emergence of the firm from bankruptcy at which time the firm essentially is transformed into a new accounting entity.

During the first part of the reorganization, the financial statements of the entity should clearly distinguish between items, events, and transactions directly associated with the reorganization and items associated with the ongoing operations of the firm. The entity will follow normal historical cost GAAP with some notable exceptions. The balance sheet should distinguish between pre-petition liabilities that are subject to compromise and post-petition liabilities that are not subject to compromise. On the income statement, all items associated with the reorganization should be reported separately as "reorganization items."

The second part is the emergence of the firm as a new accounting entity. An entity that has filed for Chapter 11 bankruptcy protection and whose reorganization plan has been confirmed by the bankruptcy court is essentially deemed to be a new company from an accounting standpoint and must adopt fresh-start reporting if the following two conditions are met: 
1. The reorganization value of the assets of the emerging entity immediately before the date of the confirmation is less than the total of all post-petition liabilities and allowed claims, and

2. Holders of existing voting shares immediately before confirmation receive less than 50 percent of the voting shares of the emerging entity.

Reorganization value should generally approximate fair value of the entity before considering liabilities and approximates the amount a willing buyer would pay for the assets of the entity immediately before the restructuring. Generally, reorganization value is determined by discounting future cash flows from the reconstituted business as it emerges from Chapter 11 and from expected proceeds or collections from assets not required in the reconstituted business.

The emerging entity should prepare its initial financial statements in accordance with the following rules:

1. Retained earnings should be reported at zero.

2. Reorganization value should be allocated to assets in conformity with APB Opinion No. 16, "Business Combinations."

3. Any reorganization value in "excess of amounts allocable to identifiable assets" should be reported as an intangible asset and amortized in accordance with GAAP.

4. Liabilities existing at the confirmation date should be reported at present values of amounts to be paid determined at appropriate current interest rates.

5. Deferred taxes should be reported in conformity with GAAP.

6. Changes in accounting principles required in the 12 months following fresh-start reporting should be adopted at the time fresh-start reporting is adopted.

The notes to the fresh-start financial statements should disclose the following:

1. Adjustments to the historical amounts of individual assets and liabilities.

2. The amount of debt forgiven.

3. The amount of prior retained earnings or deficit eliminated.

4. Significant matters relating to the determination of reorganization value such as:

a. $\quad$ Method used to determine reorganization value.

b. Sensitivity assumptions.

c. Assumptions about anticipated conditions.

In addition, SOP 90-7 states that comparative financial statements that straddle a confirmation date should not be presented.

\section{Principles vs. rules}

One of the primary differences between GAAP and IFRS is that GAAP is generally seen as a rules-based system, while IFRS is seen as a principles-based system. The general feeling is that a rules-based system may be more open to abuse than a principles-based system.

During the Enron scandal, Arthur Andersen was accused of attesting to the fairness of financial statements that met the technical requirements of GAAP while violating the intent of GAAP. This scandal illustrates a classic case of "form over substance," or the letter vs. the spirit of the law. A rules-based system allows managers to ignore the substance of financial statements and, instead, search the rules for reasons they can't do something. Some believe rules-based accounting standards allow entities to stretch the limits of what is permissible under the law, even though it may not present the true financial position of the entity. A principles-based system requires companies to report, and auditors to audit, the substance or business purpose of transactions; not merely whether they can qualify as acceptable under highly detailed rules.

Most observers believe that IFRS are more principles-based than U.S. GAAP. These principles-based accounting standards emphasize the spirit of the accounting rules rather than strict adherence to a set of written requirements. 


\section{CURRENT REPORTING OF BANKRUPTCY ACCOUNTING}

In order to gain an understanding of the way that reorganization bankruptcies are reported in countries subject to IFRS, an investigation of the reporting of companies recently undergoing reorganization bankruptcies in countries using IFRS was conducted. An initial impression is that fresh-start accounting as required by ASC 852 is prohibited under IFRS. The following excerpt from the PGS company of Norway illustrates this point.

In connection with PGS' emergence from Chapter 11 reorganization, PGS adopted "fresh-start" reporting for financial statement purposes under US GAAP, effective November 1, 2003, in accordance with Statement of Position 90-7. Due to the change in ownership resulting from the reorganization, under "fresh-start" accounting, PGS must reflect its net asset as if it was acquired in a business combination. Accordingly PGS adjusted the recorded value of its assets and liabilities to reflect their fair value as of the date it emerged from Chapter 11 reorganization. This significantly changed the book value of several of the assets and liabilities of PGS. Fresh-start accounting as applied by PGS under U.S. GAAP in conjunction with Chapter 11 is not permitted under current IFRS, hence such fair value adjustments have been removed when applying IFRS.

Fresh-start reporting is not an allowed alternative under IFRS; hence the effects of fresh start reporting have to be removed in the IFRS Financial Statements. For the most part this has implied replacing fresh start values with retrospective application of IFRS, hence to use historic values and adjust for related amortization, depreciation and impairment or reversal as required.

\section{SUMMARY}

Accounting for reorganizations under bankruptcy is somewhat of an unknown. The IASB has not issued any guidance with respect to the accounting situations which are now controlled by ASC 852 . There is a possibility that fresh start accounting will be banned in the United States if IFRS is adopted by the FASB.

However, according to the hierarchy of IFRS, the preparer should turn to national standards if the other levels of the hierarchy do not address the issues at hand.

Fresh start accounting has been debated in relation to business combinations. If fresh start accounting were allowed in business combinations, a new entity for accounting purposes would result from the business combination. As required by ASC 852, the fair values of the assets and liabilities of all entities involved in the business combination at the acquisition date would be measured and these values would be used as the opening values in the books of the newly combined entity. IFRS 3 (IASC, 2008) requires that the acquisition method of accounting be applied to all business combinations within the scope of the standard without exception. Research by the IASB is continuing on business combinations and the Board may debate the application of Fresh Start Accounting as part of Phase II of the business combinations project.

\section{AUTHOR INFORMATION}

Daniel L. Haskin, PhD, CPA is Professor of Accounting at the University of Central Oklahoma in Edmond, Oklahoma. His primary research interests are in financial accounting and cost and managerial accounting. E-mail: DHaskin@uco.edu. Corresponding author.

Teresa E. Haskin, MBA, CPA is a CPA in public practice in Edmond, Oklahoma for the last eleven years. She has recently been an adjunct instructor at the University of Central Oklahoma and Oklahoma State University at Oklahoma City. Her research interests are financial accounting and taxation. E-mail: dthaskin@swbell.net.

\section{REFERENCES}

1. AICPA. (1990). Statement of Position 90-7: Financial Reporting by Entities in Reorganization Under the Bankruptcy Code. New York: AICPA. 
2. AICPA. (1992). Auditing Standard No. 69, The Meaning of Present Fairly in Conformity with Generally Accepted Accounting Principles. New York: AICPA.

3. FASB. (2008). Statement on Financial Accounting Standards No. 162, The Hierarchy of Generally Accepted Accounting Principles. Stamford: FASB.

4. FASB. (2009). Statement of Financial Accounting Standards No. 168, The FASB Accounting Standards Codification and the Hierarchy of Generally Accepted Accounting Principles - a replacement of FASB Statement No. 162. Stamford: FASB.

5. House of Commons Library (2010). A Comparison: Company Rescue under UK Administration and US Chapter 11. London: House of Commons.

6. IASB. (2008). IAS 3 Business Combinations. London: IASB.

7. IASB, (2003). IAS 8 Accounting Policies, Changes in Accounting Estimates and Errors. London: IASB.

8. PGS. (2007). Transition to International Financial Reporting Standards (IFRS), Lysaker, Norway: PGS. 